\title{
Hospital hand hygiene opportunities: where and when (HOW2)?
}

\author{
CJ Steed ${ }^{1 *}$, JW Kelly ${ }^{2}$, D Blackhurst ${ }^{3}$, S Boeker ${ }^{1}$, P Alper ${ }^{4}$, E Larson $^{5}$ \\ From International Conference on Prevention \& Infection Control (ICPIC 2011) \\ Geneva, Switzerland. 29 June - 2 July 2011
}

\section{Introduction / objectives}

The purpose of this study was to estimate hand hygiene opportunities (HHOs) in two types of hospitals - largeteaching and small-community, and three different clinical areas - medical-surgical intensive care, general medical wards, and emergency departments.

\section{Methods}

Hand hygiene opportunity data were collected through direct observations using the World Health Organization's (WHO) monitoring methodology. Estimates of HHOs were developed for 12-hour AM/PM shifts and 24-hour time frames.

\section{Results}

During 436.7 hours of observation, 6640 HHOs were identified. Estimates of HHOs ranged from 30 to 179 per patient day on inpatient wards and 1.84 to 5.03 per bed hour in emergency departments. Significant differences in HHOs were found between the two hospital types and between the three clinical areas.

\section{Conclusion}

This study is the first to use WHO data collection methodology to estimate $\mathrm{HHO}$ in general medical wards and emergency departments. These data can be used as denominator estimates to calculate hand hygiene compliance rates when product utilization data are available.

\section{Disclosure of interest}

C. Steed Grant/Research support from DebWorldwide, J. Kelly Grant/Research support from DebWorldwide, D. Blackhurst Grant/Research support from DebWorldwide, S. Boeker Employee of DebWorldwide, P. Alper:

Infection Prevention and Control, Greenville SC, USA

Full list of author information is available at the end of the article
None declared, E. Larson Grant/Research support from DebWorldwide.

\section{Author details}

${ }^{1}$ Infection Prevention and Control, Greenville SC, USA. ${ }^{2}$ Greenville Hospital System University Medical Cent, Greenville SC, USA. ${ }^{3}$ Quality Management, ${ }^{2}$ Greenville Hospital System University Medical Cent, Greenville SC, USA. ${ }^{4}$ Research and Development, Deb Worldwide Healthcare, Inc, Stanley, NC, USA. ${ }^{5}$ School of Nursing, Columbia University, NewYork, USA.

Published: 29 June 2011

doi:10.1186/1753-6561-5-S6-P112

Cite this article as: Steed et al:: Hospital hand hygiene opportunities: where and when (HOW2)? BMC Proceedings 2011 5(Suppl 6):P112.

Submit your next manuscript to BioMed Central and take full advantage of:

- Convenient online submission

- Thorough peer review

- No space constraints or color figure charges

- Immediate publication on acceptance

- Inclusion in PubMed, CAS, Scopus and Google Scholar

- Research which is freely available for redistribution

Submit your manuscript at www.biomedcentral.com/submit
() Biomed Central 